Article

\title{
Liming and Phosphate Application Influence Soil Carbon and Nitrogen Mineralization Differently in Response to Temperature Regimes in Allophanic Andosols
}

\author{
Chihiro Matsuoka-Uno ${ }^{1}$, Toru Uno ${ }^{1}$, Ryosuke Tajima ${ }^{1}$, Toyoaki Ito ${ }^{1,2}$ and Masanori Saito ${ }^{1,3, *(D)}$ \\ 1 Field Science Center, Graduate School of Agricultural Science, Tohoku University, Osaki 989-6711, Japan; \\ c.matsuoka91@gmail.com (C.M.-U.); uno@tohoku.ac.jp (T.U.); tazy@tohoku.ac.jp (R.T.); \\ toyoaki-ito@nafu.ac.jp (T.I.) \\ 2 Food Industry Department, Niigata Agro-Food University, Niigata 959-2702, Japan \\ 3 Faculty of Agriculture, Iwate University, Morioka 020-8550, Japan \\ * Correspondence: masanori.saito.b6@tohoku.ac.jp
}

check for updates

Citation: Matsuoka-Uno, C.; Uno, T.; Tajima, R.; Ito, T.; Saito, M. Liming and Phosphate Application Influence Soil Carbon and Nitrogen Mineralization Differently in Response to Temperature Regimes in Allophanic Andosols. Agriculture 2022, 12, 142. https://doi.org/ 10.3390/agriculture12020142

Academic Editor: Laura Zavattaro

Received: 9 December 2021

Accepted: 20 January 2022

Published: 21 January 2022

Publisher's Note: MDPI stays neutral with regard to jurisdictional claims in published maps and institutional affiliations.

Copyright: (C) 2022 by the authors. Licensee MDPI, Basel, Switzerland. This article is an open access article distributed under the terms and conditions of the Creative Commons Attribution (CC BY) license (https:// creativecommons.org/licenses/by/ $4.0 /)$.

\begin{abstract}
Andosols are characterized by high organic matter content and play a significant role in carbon storage. However, they have low phosphorus fertility because of the high phosphate-fixing capacity of active aluminum. For agricultural use of Andosols, it is necessary to ameliorate its poor phosphorus fertility by applying lime and high doses of phosphate fertilizers. The objective of the present study was to clarify how such soil amendments affect the mineralization of soil organic carbon $(\mathrm{C})$ and nitrogen $(\mathrm{N})$ in allophanic Andosols under different temperature regimes. The soil was treated using combinations of liming and heavy phosphate application, followed by incubation under different temperature conditions. The $\mathrm{N}$ mineralization and the soil $\mathrm{CO}_{2}$ evolution rate were measured periodically. The patterns of $\mathrm{N}$ mineralization were analyzed by fitting them to first-order kinetics. Liming increased $\mathrm{C}$ and $\mathrm{N}$ mineralization irrespective of temperature, and the increase was further enhanced by phosphate application. Kinetic analysis of the $\mathrm{N}$ mineralization curve indicated lowering of the activation energy of $\mathrm{N}$ mineralization reactions with phosphate application, suggesting that $\mathrm{P}$ application may accelerate $\mathrm{N}$ mineralization at lower temperatures. These findings provide a basis for developing soil management strategies to reduce the loss of soil organic matter.
\end{abstract}

Keywords: Andosols; soil carbon; global warming; phosphorus; phosphate; liming; nitrogen; mineralization; temperature

\section{Introduction}

A huge amount of carbon (C), $1500 \mathrm{Pg} \mathrm{C}$, approximately twice the amount present in the atmosphere and thrice the amount in terrestrial plant biomass, is stored in the soil as organic matter [1]. Furthermore, any variation in the soil organic matter content significantly impacts the global carbon cycle. In arable soils, the amount of soil C is strongly influenced by environmental factors such as temperature and agricultural management practices such as tillage. Life-cycle inventory analysis of greenhouse gases (GHGs) in various crop production systems in northern Japan revealed that carbon dioxide $\left(\mathrm{CO}_{2}\right)$ emissions from soil were the largest source of GHG emissions [2]. Various reports have warned that the increase in decomposition of soil organic matter due to global warming will further accelerate the atmospheric $\mathrm{CO}_{2}$ concentration [3-5]. In order to take countermeasures against global warming, it is essential to predict the potential changes in soil C status in response to environmental changes and human activities (such as agricultural soil management practices).

Andosols are of volcanic origin and are one of the most widely distributed soils in Japan (31\% of the country's land area and $47 \%$ of upland arable fields) [6]. Andosols are characterized by high organic matter content, resulting in high soil $\mathrm{C}$ storage capacity and 
excellent physical and water retention properties. However, they have low phosphorus fertility because of the high phosphate-fixing capacity of active aluminum. For agricultural use of Andosols in Japan, when uncultivated Andosols are converted into arable lands, it is recommended to ameliorate the soil by applying a mixture of phosphate fertilizers (e.g., fused phosphate and superphosphate) equivalent to $10 \%$ of the phosphate absorption coefficient (PAC) of the soil [7]. Such large amounts of phosphate fertilization not only increase the amount of available phosphate in the soil, but also increase phosphorus fertility of the soil by masking some of the phosphate fixing sites of clay particles and decreasing the phosphorus adsorption capacity [6,8]. These amendments may increase the activity of soil microorganisms that were previously limited by the phosphorous deficiency and acidity of the soil and may promote the decomposition of soil organic matter. Munevar and Wollum [9] reported that the addition of phosphate and $\mathrm{N}$ increased the mineralization of soil organic C and $\mathrm{N}$ in the Andosols of Colombia. Ogasawara et al. [10] reported that soil $\mathrm{N}$ mineralization increased with the addition of a mixture of fused phosphate and superphosphate in the Andosols of northern Japan. These incubation experiments were conducted at about $30^{\circ} \mathrm{C}$. However, in the northern part of Japan under cool-temperate climate, the average annual soil temperature is $10-15^{\circ} \mathrm{C}$ and rarely exceeds $25^{\circ} \mathrm{C}$, even in summer. Although a large number of studies on temperature dependency of soil organic matter decomposition have been reported, e.g., [3-5], the effect of soil amendments on soil organic matter decomposition focusing on temperature regime has rarely been reported.

The objective of the present study was to clarify how these soil amendments affect mineralization of soil organic $C$ and $N$, with an emphasis on temperature response. We hypothesize that soil available phosphate limits $C$ and $N$ mineralization in an allophanic Andosol and that this effect is more evident in lower temperature regime. In the present study, we used a soil sample from an uncultivated land with an allophanic Andosols under cool-temperate climate (annual mean temperature $10.6{ }^{\circ} \mathrm{C}$ ) and treated the soil with different combinations of lime and phosphate. Phosphate was applied at the rate of 5\% and $20 \%$ of PAC, as indicated in the study by Yamamoto and Miyasato [7]. Mineralization of soil organic carbon and nitrogen was examined by incubating the soil under different temperature regimes.

\section{Materials and Methods}

\subsection{Soil}

The soil was collected from the surface layer $(0-20 \mathrm{~cm})$ of an uncultivated land $\left(39^{\circ} 44^{\prime} 56.4^{\prime \prime} \mathrm{N}, 141^{\circ} 08^{\prime} 16.8^{\prime \prime} \mathrm{E}\right)$ under Pinus densiflora trees in Morioka City, Iwate Prefecture, Japan, after removing the litter layer of soil. The physicochemical properties of the soil were as follows: texture, $\mathrm{LiC}$; total C, $186 \mathrm{~g} \mathrm{C} \mathrm{kg}^{-1}$ dry soil; total $\mathrm{N}, 11.7 \mathrm{~g} \mathrm{~N} \mathrm{~kg}^{-1}$ dry soil; ammonium $\mathrm{N}, 63 \mathrm{mg} \mathrm{N} \mathrm{kg}^{-1}$ dry soil; nitrate $\mathrm{N}, 65 \mathrm{mg} \mathrm{N} \mathrm{kg}^{-1}$ dry soil; $\mathrm{pH}$ $\left(\mathrm{H}_{2} \mathrm{O}\right), 5.3$; PAC (phosphate absorption coefficient), $23.3 \mathrm{~g} \mathrm{P}_{2} \mathrm{O}_{5} \mathrm{~kg}^{-1}$ dry soil; available phosphate, $0.016 \mathrm{~g} \mathrm{P}_{2} \mathrm{O}_{5} \mathrm{~kg}^{-1}$ dry soil (Truog method); maximum water holding capacity, $0.80 \mathrm{~cm}^{3} / \mathrm{cm}^{3}$. Analytical methods of soil are described in the Supplementary Materials. The soil was classified as an allophanic cumulic Andosol according to the Soil Classification System of Japan [6].

\subsection{Design for Incubation Experiment}

Fresh, moist soil samples that were air-dried, sieved through a $2 \mathrm{~mm}$ mesh, and treated with different levels of phosphate and lime were used for the incubation experiment. In the non-liming treatment, two levels of potassium phosphate monobasic ( $0 \%$ for control, $5 \%$ and $20 \%$ of PAC; equivalent to about $11.6 \mathrm{Mg} \mathrm{P}_{2} \mathrm{O}_{5} \mathrm{ha}^{-1}, 46.6 \mathrm{MgP}_{2} \mathrm{O}_{5} \mathrm{ha}^{-1}$ ) were added to the soil samples. In the liming treatment, calcium hydroxide $\left(5.5 \mathrm{~g} \mathrm{~kg}^{-1} \mathrm{dry}\right.$ soil $)$ was used to adjust the soil $\mathrm{pH}$ (to $\sim 6.0$ ) before adding potassium phosphate at the rate of $0 \%$, $5 \%$, and $20 \%$ of PAC. Soil sample was incubated for each treatment in triplicate (see the Supplementary Materials). The incubation temperatures were 20 and $30{ }^{\circ} \mathrm{C}$. An additional temperature level, $25^{\circ} \mathrm{C}$, was set for $\mathrm{N}$ mineralization in the non-liming treatment, because 
preliminary experiment showed another temperature level may be required for more reliable kinetic parameters of $\mathrm{N}$ mineralization (Section 2.4) in the non-liming treatment.

The treated soil samples were put in separate $100 \mathrm{~mL}$ polyethylene vials, individually covered with aluminum foil, and incubated for 120 days. Throughout the incubation period, the soil moisture condition was maintained at $50 \%$ of the maximum water holding capacity of the soil. The $\mathrm{pH}\left(\mathrm{H}_{2} \mathrm{O}\right)$ and available phosphate content (Truog method) of the soil samples were measured periodically throughout the incubation period.

\subsection{Mineralization: $\mathrm{CO}_{2}$ Evolution}

Organic $\mathrm{C}$ mineralization was estimated by periodically measuring the rate of $\mathrm{CO}_{2}$ evolution from the soil (Figure S1). The aluminum foil was removed from the incubated samples, and the polyethylene vials were individually placed in $485 \mathrm{~mL}$ wide-mouthed glass bottles with a septum for gas sampling. The bottles were incubated at the respective incubation temperatures. About $1 \mathrm{~h}$ and $24 \mathrm{~h}$ after the bottles were incubated, $1 \mathrm{~mL}$ gas was collected from the bottle using a gas-tight syringe, and the $\mathrm{CO}_{2}$ concentration was measured using a gas chromatograph (GC-8A, Shimadzu, Kyoto, Japan) equipped with a thermal conductivity detector and a Shincarbon ST column (Shinwa Chemical Industries Ltd., Kyoto, Japan). The $\mathrm{CO}_{2}$ evolution rate was calculated from the increase in the $\mathrm{CO}_{2}$ concentration during this period. The soils in the polyethylene vials after $\mathrm{CO}_{2}$ assay were back to the incubator for further $\mathrm{CO}_{2}$ evolution measurement.

\subsection{N Mineralization}

After the designated incubation period, mineral $\mathrm{N}$ was extracted from the soil samples using $2 \mathrm{~N} \mathrm{KCl}$. The nitrate- $\mathrm{N}$, nitrite- $\mathrm{N}$, and ammonium- $\mathrm{N}$ contents of each extract were estimated using an autoanalyzer (QuAAtro 2-HR, BL-TECH Co., Tokyo, Japan), and the sum of these $\mathrm{N}$ values was considered as the mineral $\mathrm{N}$ content of the respective sample.

\subsection{Kinetic Analysis of N Mineralization Curve}

The mineral $\mathrm{N}$ contents obtained in this study were presented in the form of a $\mathrm{N}$ mineralization curve, which was analyzed using the method proposed by Sugihara et al. [11]. This method assumes that the $\mathrm{N}$ mineralization curve corresponds to an equation of the first-order reaction (Equation (1)), and the relationship between the mineralization rate constant and temperature follows the Arrhenius law (Equation (2)).

$$
\begin{aligned}
\mathrm{N}_{\mathrm{t}} & =\mathrm{N}_{0}\{1-\exp (-\mathrm{k} \cdot \mathrm{t})\} \\
\mathrm{k} & =\mathrm{A} \cdot \exp (-\mathrm{Ea} / \mathrm{R} \cdot \mathrm{T})
\end{aligned}
$$

where $\mathrm{N}_{\mathrm{t}}$ and $\mathrm{N}_{0}$, amount of mineralized $\mathrm{N}$ at time $t$ and infinite time, respectively ( $\mathrm{mg} \mathrm{N} \mathrm{kg}{ }^{-1}$ soil); $\mathrm{k}$, mineralization rate constant $\left(\mathrm{day}^{-1}\right)$; Ea, activation energy $\left(\mathrm{kJ} \mathrm{mol}^{-1}\right) ; \mathrm{T}$, absolute temperature $(\mathrm{K})$; $\mathrm{R}$, universal gas constant $\left(8.31 \mathrm{~J} \mathrm{~mol}^{-1} \mathrm{~K}^{-1}\right)$; $\mathrm{A}$, Arrhenius constant.

Curve fitting of the data was performed using the Solver program of Microsoft Excel 2019 (Microsoft Corporation, Redmond, WA, USA). Fitness was evaluated on the basis of the minimum Akaike information criterion values. Parameters obtained by this nonliner curve fitting were compared among the treatments by Bonfferoni method (see the Supplementary Materials).

\subsection{Statistical Analyses}

Statistical analyses were conducted using the JMP software (SAS Institute Japan, Tokyo, Japan) and the data analyses tools of Microsoft Excel 2019.

\section{Results}

\subsection{Change of Available Phosphate and $\mathrm{pH}$ of Soil during Incubation}

The changes in $\mathrm{pH}$ are shown in Figure 1. The $\mathrm{pH}$ of soil samples subjected to liming treatment was initially adjusted to $\approx 6.0$. In all treatments, the $\mathrm{pH}$ gradually decreased, 
probably due to the accumulation of nitrate $\mathrm{N}$, while a small increase in $\mathrm{pH}$ during the early incubation period was found in some treatments. Overall, the change in $\mathrm{pH}$ during the incubation period was within one unit.
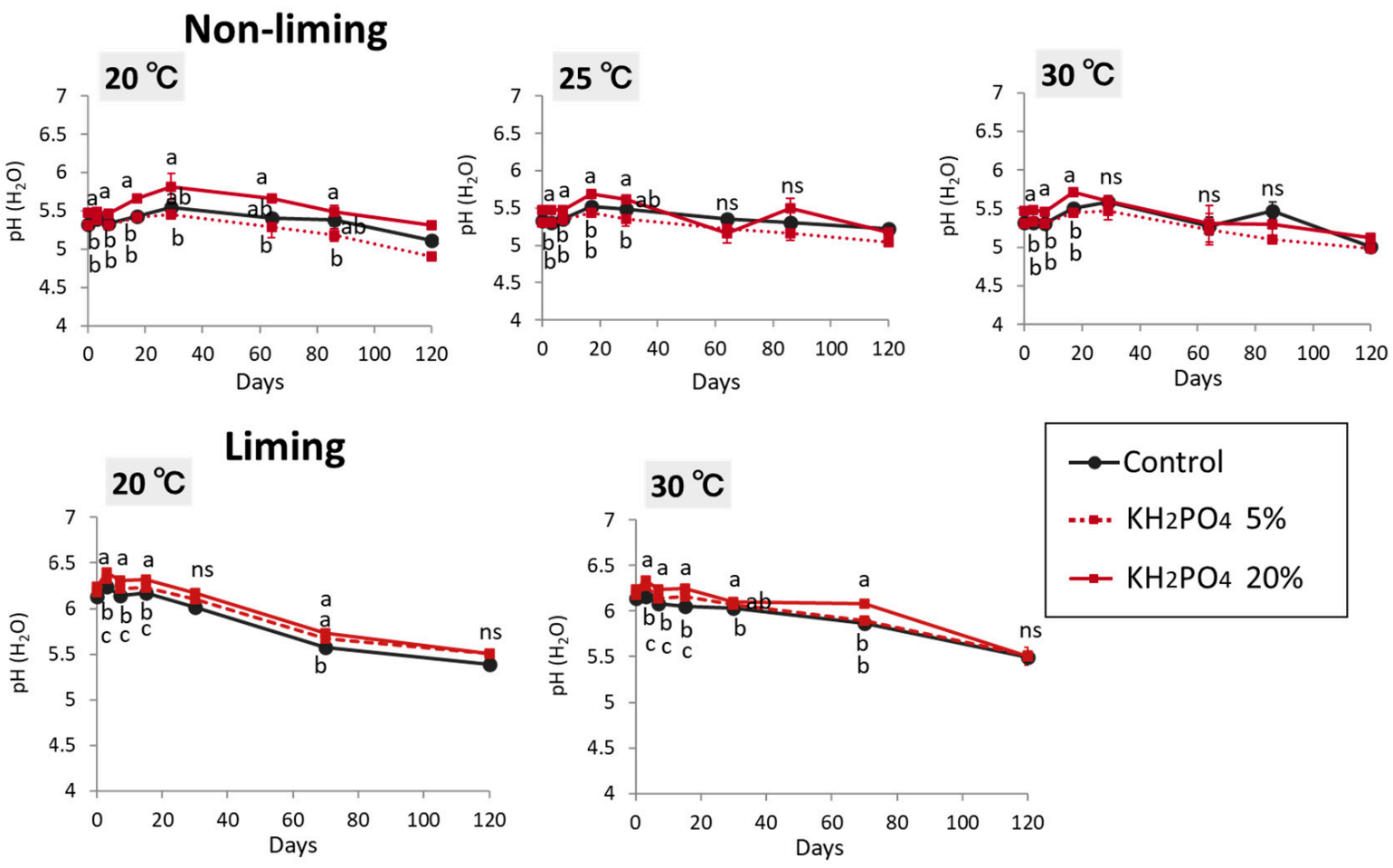

Figure 1. Change of soil $\mathrm{pH}\left(\mathrm{H}_{2} \mathrm{O}\right)$ during the incubation period. Vertical bars indicate the standard error of means $(n=3)$. Different letters indicate significantly different on the same day (Tukey's multiple comparison test, ns; not significantly different). The data on day 120 in non-liming treatment were not replicated, and therefore the statistical analyses were not performed.

The change in the available phosphate at $20^{\circ} \mathrm{C}$ is shown in Figure 2. The trend at $30{ }^{\circ} \mathrm{C}$ was almost the same as that observed at $20^{\circ} \mathrm{C}$ (data not shown). Available phosphate decreased immediately after the addition of potassium phosphate due to the quick fixation of phosphate, and then remained constant, for both application levels. In the liming treatment, the amount of available phosphate was higher than that in the non-liming treatment. It may have been due to a somewhat higher $\mathrm{pH}$ in the liming treatment.

\section{2. $\mathrm{CO}_{2}$ Evolution}

The change in the rate of $\mathrm{CO}_{2}$ evolution from the soil during the incubation period is shown in Figure 3. The pattern of changes in the $\mathrm{CO}_{2}$ evolution rate differed between the non-liming and liming treatments. In the non-liming treatment, the $\mathrm{CO}_{2}$ evolution rate increased with time, peaked at 40-50 days, and then decreased. However, liming treatment increased the overall $\mathrm{CO}_{2}$ evolution rate of the soil, compared to the non-liming treatment. There was a peak in $\mathrm{CO}_{2}$ evolution at the beginning of the incubation period, followed by a decline and a small peak at $\approx 40$ days, similar to that in the non-liming treatment. The total $\mathrm{CO}_{2}$ evolution during the incubation period (Figure 4) was estimated by integrating the curves of the $\mathrm{CO}_{2}$ evolution rate up to 84 days. In the non-liming treatment, phosphate application was not significant in terms of the total amount of $\mathrm{CO}_{2}$ evolved. In contrast, in the liming treatment, phosphate application increased total $\mathrm{CO}_{2}$ evolution at $30^{\circ} \mathrm{C}$ (Figure 4). 


\section{at $20^{\circ} \mathrm{C} \quad$ Non-liming}

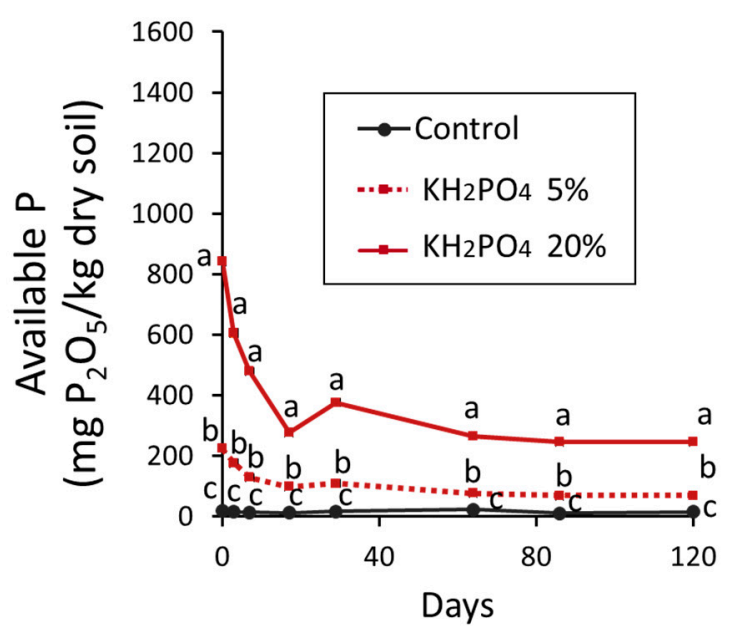

Liming

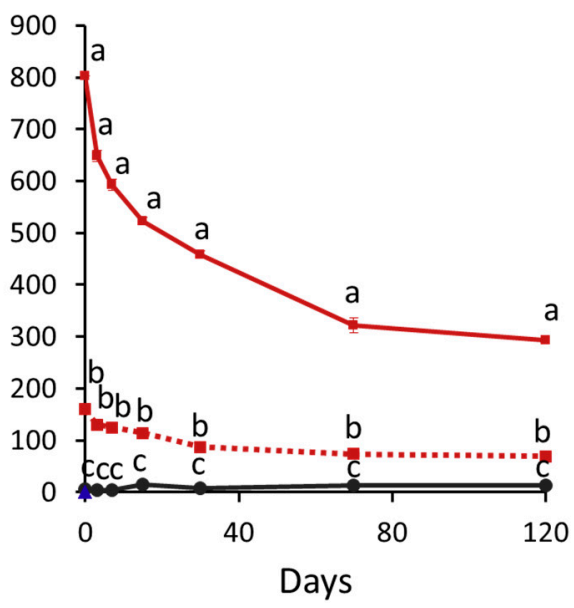

Figure 2. Change of available phosphate in soil (Truog method) at $20^{\circ} \mathrm{C}$. Vertical bars indicate the standard error of means $(n=3)$. Different letters indicate significantly different on the same day (Tukey's multiple comparison test).

\section{Non-liming}

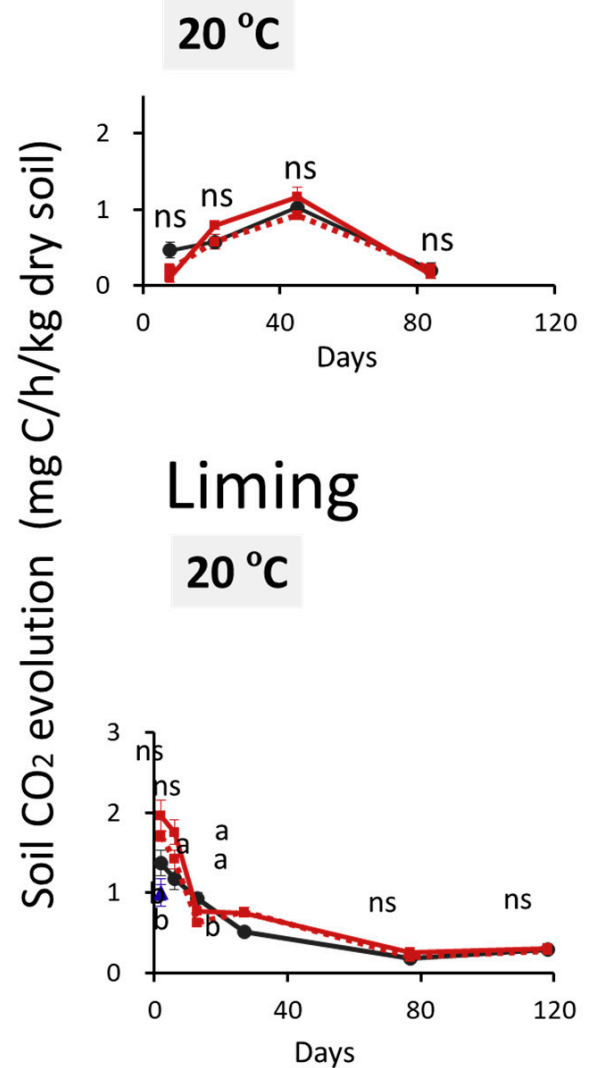

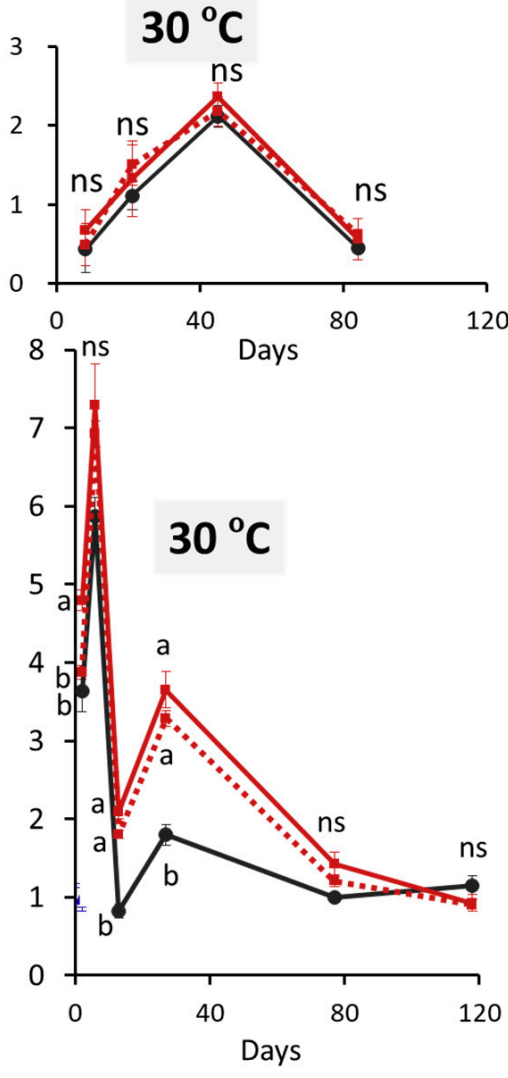

$\rightarrow$ Control $\cdots \cdots \mathrm{KH}_{2} \mathrm{PO}_{4} 5 \% \rightarrow \mathrm{KH}_{2} \mathrm{PO}_{4} 20 \%$

Figure 3. $\mathrm{CO}_{2}$ evolution rates at different temperatures. Vertical bars indicate the standard error of means $(n=3)$. Different letters indicate significantly different at each temperature (Tukey's multiple comparison test; ns, not significantly different). 

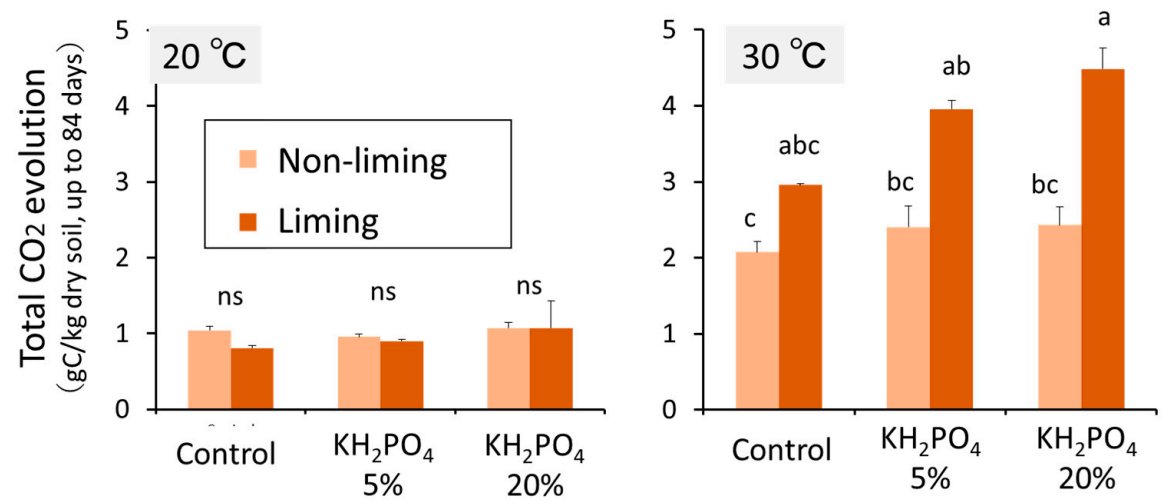

Figure 4. Total $\mathrm{C}$ mineralization estimated up to 84 days by $\mathrm{CO}_{2}$ evolution rate at different temperatures. Vertical bars indicate the standard error of means $(n=3)$. Different letters indicate significantly different at each temperature (Tukey's multiple comparison test; ns, not significantly different). Two ways ANOVA (temperature $\times$ liming) showed both temperature and liming treatments showed $p<0.01$. Since the $\mathrm{CO}_{2}$ evolution data at $20^{\circ} \mathrm{C}$ were obtained only up to day 84 (Figure 3), total $\mathrm{CO}_{2}$ evolution at $30^{\circ} \mathrm{C}$ was also estimated up to day 84 . The data for day 84 in the liming treatment was extrapolated from the data for day 77 and day 120.

\subsection{N Mineralization Curves and Their Kinetic Analysis}

The accumulation of mineral $\mathrm{N}$ in the soil during the incubation period is shown in Figure 5. In the non-liming treatment, $\mathrm{N}$ mineralization at $20^{\circ} \mathrm{C}$ increased with the application of phosphate at the rate of $20 \%$ PAC. In the liming treatment, $\mathrm{N}$ mineralization increased to some degree for both levels of phosphate application. The $\mathrm{N}$ mineralization parameters were obtained by fitting the $\mathrm{N}$ mineralization curve to the first-order reaction (Table 1). The mineralization rate constants were not significantly affected by both phosphate application and liming. The activation energy (Ea) in the non-liming treatment significantly decreased with phosphate application ( $20 \%$ of PAC). Liming increased the amount of potentially mineralizable $\mathrm{N}\left(\mathrm{N}_{0}\right)$.

\section{Non-liming}
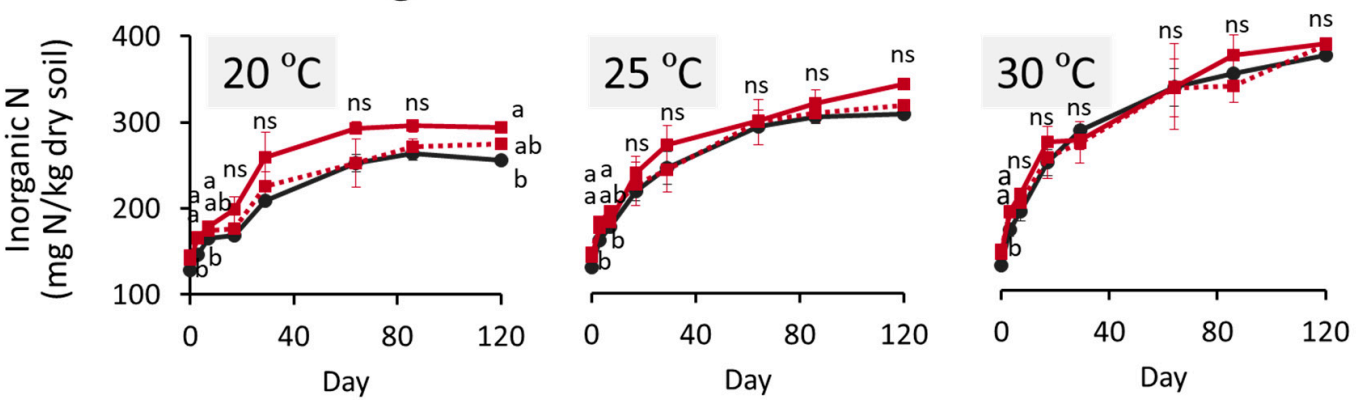

Liming
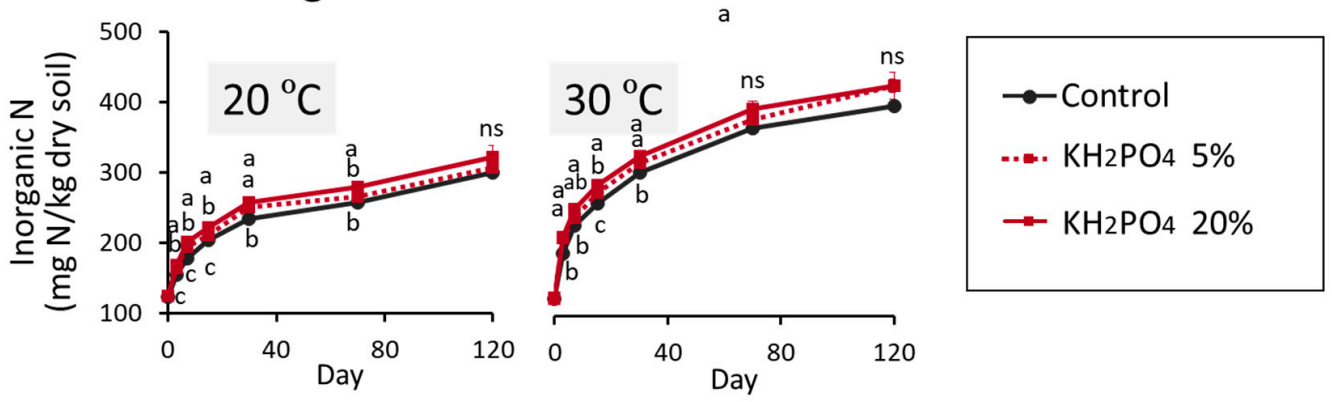

Figure 5. Change of mineral $\mathrm{N}$ in soils at different incubation treatments and temperatures. Vertical bars indicate the standard error of means $(n=3)$. Different letters indicate significant difference at each temperature (Tukey's multiple comparison test; ns, not significantly different). 
Table 1. Nitrogen mineralization parameters of soil incubated at different treatments and temperatures.

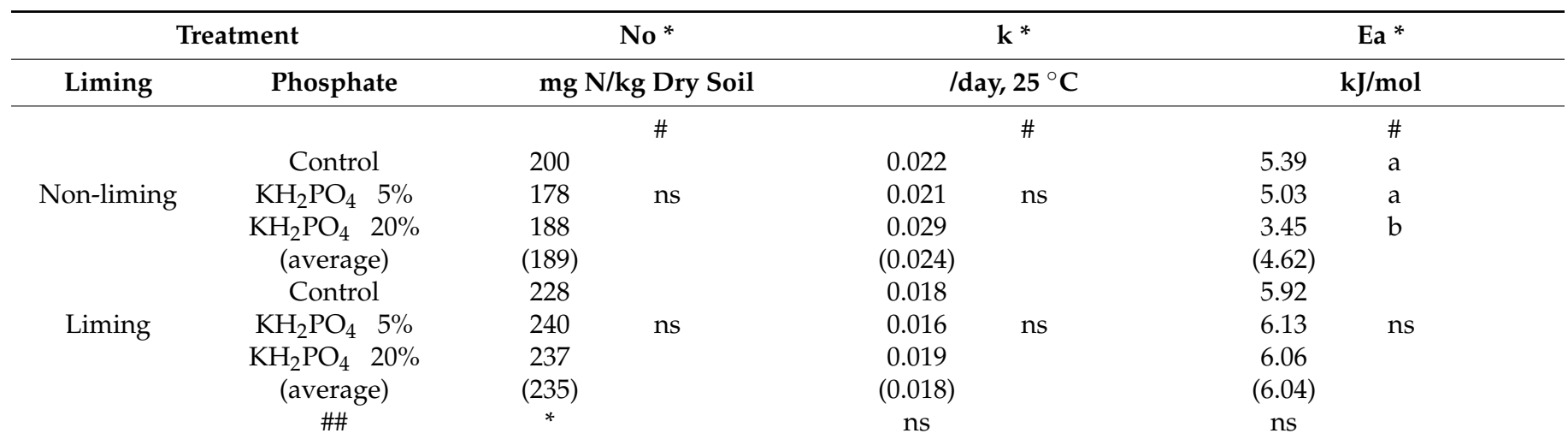

${ }^{*}$ No, potentially mineralizable $\mathrm{N}$; $\mathrm{k}$, mineralization rate constant; Ea, activation energy. \# Different letters $(\mathrm{a}, \mathrm{b})$ indicate statistical significance among phosphate addition treatments by the Bonferroni method $(p<0.05$, ns: not significant). \#\# Statistical difference between the non-liming and liming treatments ( ${ }^{*}: p<0.05$, ns: not significant).

\section{Discussion}

In the present study, we examined the effects of liming and heavy phosphate application on $\mathrm{C}$ and $\mathrm{N}(\mathrm{N})$ mineralization in soil samples from the uncultivated allophanic Andosols of Japan.

The effect of liming showed the same trend irrespective of the temperature. Liming increased the rate of $\mathrm{CO}_{2}$ evolution during the early stages of incubation (Figure 3). The $\mathrm{N}$ mineralization curve also showed the same trend-liming increased $\mathrm{N}$ mineralization in the initial stages of incubation. This result was supported by the kinetic analysis of the $\mathrm{N}$ mineralization curve, which showed that $\mathrm{N}$ mineralization potential, $\mathrm{N}_{0}$, was increased by liming (Table 1).

In contrast, the effect of phosphate application varied with liming and incubation temperature. The total $\mathrm{CO}_{2}$ evolution, which is the integrated value of the $\mathrm{CO}_{2}$ evolution during the incubation period (Figure 4), increased with phosphate application and was more pronounced at $30{ }^{\circ} \mathrm{C}$ in the liming treatments, whereas it was not as evident in the non-liming treatments. $\mathrm{N}$ mineralization in the non-liming treatment at $20{ }^{\circ} \mathrm{C}$ was promoted by phosphate application. $\mathrm{N}$ mineralization parameters based on the kinetic analysis of $\mathrm{N}$ mineralization curves showed that the activation energy, Ea, in the non-liming treatment decreased with an increase in the phosphate application rate (Table 1).

The enhancement of soil organic matter decomposition by liming is well documented [12-16]. This reaction occurs partly because of the increase in microbial activity due to the neutralization of soil acidity, and partly because of the solubilization of organic matter. Liming releases organic matter trapped in soil aggregates by the dispersion of clay. Takahashi et al. [17] reported that the addition of lime to Andosols broke down a part of the Al-humus complex and led highly humified soil organic matter to more decomposable. Another source of solubilized organic matter might be microbial biomass. Marumoto et al. [18] reported that lime application killed some microbial biomass (especially fungi) and caused a rapid growth of microorganisms that utilize the dead microbial biomass. The microorganisms responsible for mineralization immediately after liming - as observed in the early stages of incubation in the present study - are probably the newly proliferated microorganisms, "fast growers" that utilize the solubilized and easily degradable fraction of organic matter. These "fast growers" may be more active at a higher temperature $\left(30^{\circ} \mathrm{C}\right)$, and more phosphate may be required for their activity (Figure 4).

The relationship between the activation energy $(\mathrm{Ea})$ of $\mathrm{N}$ mineralization and the average available soil phosphate during the incubation period (Figure 6) shows that the increase in available phosphate leads to a decrease in Ea in the non-liming treatment, indicating that the mineralization reaction occurs more readily at lower temperatures. In 
terms of temperature dependency of organic matter decomposition, recalcitrant organic matter may show higher activation energy and thus may show its higher temperature dependency than labile organic matter [19]. In contrast to liming as discussed above, it is unlikely that the addition of phosphate may have had a significant impact on organic matter quality. In the non-liming treatments, the microorganisms involved in $\mathrm{C}$ and $\mathrm{N}$ mineralization may be "slow growers" that decompose indigenous soil organic matter. Their activity is probably slower than that of the "fast growers" observed during the early stages of liming treatments. The microorganisms might have adapted to temperatures lower than $30^{\circ} \mathrm{C}$, and their activity in this temperature range might have been enhanced by phosphate addition.

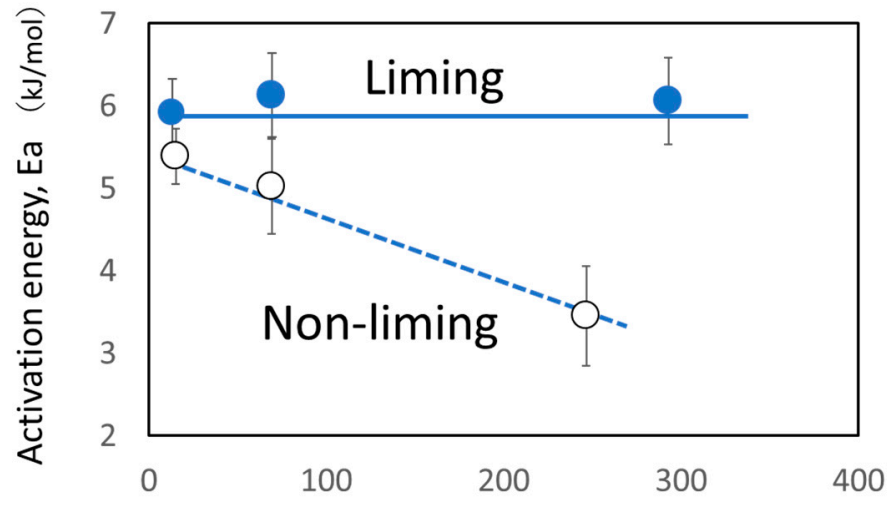

Available soil phosphate ( $\mathrm{mg}_{2} \mathrm{O}_{5} / \mathrm{kg}$ dry soil)

Figure 6. Relationship between apparent activation energy of nitrogen mineralization and available soil phosphate. The available soil phosphate (Troug method) indicated here is the average of the available soil phosphate values during the incubation period (15-120 days, $20^{\circ} \mathrm{C}$ ). Bars indicate the standard error of means $(n=3)$. Lines in figure were arbitrarily drawn.

Several studies have reported that soil $\mathrm{C}$ and $\mathrm{N}$ mineralization is limited by the phosphate availability in highly weathered tropical soils with high phosphate-fixing capacity [20,21] and in cool, temperate soils rich in organic content, such as Andosols [9,22-24]. These studies did not refer to temperature dependency of the mineralization. Saito [25] examined the $\mathrm{N}$ mineralization characteristics of various soils in the northern Tohoku region of Japan and found a negative correlation between available $p$ and Ea. This corresponds with the present result in non-liming treatment (Figure 6). Microbial populations at lower temperatures than the optimum require higher concentrations of substrates due to lowering affinity to substrate [26]. In the control soil in the non-liming treatment, available phosphate was kept very low (Figure 2), and therefore that phosphate may be deficit for microorganisms. The addition of phosphate may mitigate such phosphate deficit for soil microorganism and may result in lowering Ea. Microbial community analysis of a wide range of Japanese Andosols showed that fungal diversity decreased with increasing soil available phosphate, and Mortiellra tended to be one of the dominant fungal groups [27]. This also might be related to changes in the temperature responsiveness of $\mathrm{N}$ mineralization to phosphate application, as observed in Ea (Figure 6).

Global warming is threatening to accelerate the loss of soil organic carbon. In fact, the thawing of frozen soils in polar regions is becoming a reality [28,29]. This may be also a serious issue in cool and cold temperate regions, where soils are rich in organic matter. In Japan, higher doses of phosphate fertilizers are used in agricultural production, partly because Andosols, which have a high phosphate-fixing capacity, are widely distributed in the arable lands. This practice has increased the available phosphate in arable soils [30]. Intensive fertilization of arable soils may accelerate the loss of soil organic carbon.

For sustainable agricultural production in the changing climatic conditions, soil management practices must be improved to facilitate soil carbon storage [31]. Many studies have 
been conducted for this purpose $[32,33]$. The present study indicates that the effect of intensive fertilizer management on organic matter decomposition should be investigated more systematically and extensively, as well as being reflected in sustainable soil management.

\section{Conclusions}

Conversion of uncultivated Andosols to arable lands generally requires liming treatments and heavy phosphate applications to improve crop production $[6,8]$. The effects of liming and heavy application of phosphate on soil $\mathrm{C}$ and $\mathrm{N}$ mineralization in allophanic Andosols were investigated under different temperature regimes. Liming led highly humified organic matter to more decomposable $[16,17,24]$ and increased the easily degradable fraction of organic matter, and as a result, the microbial communities that proliferated using these fractions became more active with the application of high amounts of phosphate. In contrast, in the non-liming treatment, phosphate increased soil $\mathrm{N}$ mineralization at lower temperatures. These findings support our hypothesis raised in the Introduction section and also provide a basis for the development of a model for predicting soil $\mathrm{C}$ and $\mathrm{N}$ mineralization. The model may contribute to the development of management strategies to reduce the loss of soil organic matter in the face of global warming.

Supplementary Materials: The following are available online at https:/ /www.mdpi.com/article/ 10.3390/agriculture12020142/s1, Analytical methods of soil, Incubation of soil, Curve fitting of N mineralization curve. Figure S1: Measurement of soil $\mathrm{CO}_{2}$ evolution rate.

Author Contributions: Conceptualization, M.S.; methodology, C.M.-U., T.U., R.T., T.I. and M.S.; data analysis, C.M.-U., R.T. and M.S.; writing, C.M.-U. and M.S. All authors have read and agreed to the published version of the manuscript.

Funding: This research was in-part supported by ESPEC Foundation for Global Environment Research and Technology (ESPEC Prize for the Encouragement of Environmental Studies).

Data Availability Statement: The data presented in this study are available on request from the corresponding author.

Acknowledgments: We are grateful to Shintaro Hara for his technical support of gas chromatographic analysis.

Conflicts of Interest: The authors declare no conflict of interest.

\section{References}

1. IPCC. Climate Change 2001: The Scientific Basis; Cambridge University Press: Cambridge, UK, 2001; pp. 1-944.

2. Koga, N.; Sawamoto, T.; Tsuruta, H. Life cycle inventory-based analysis of greenhouse gas emissions from arable land farming systems in Hokkaido, northern Japan. Soil Sci. Plant Nutr. 2006, 52, 564-574. [CrossRef]

3. Crowther, T.W.; Todd-Brown, K.E.; Rowe, C.W.; Wieder, W.R.; Carey, J.C.; Machmuller, M.B.; Snoek, B.L.; Fang, S.; Zhou, G.; Allison, S.D.; et al. Quantifying global soil carbon losses in response to warming. Nature 2016, 540, 104-108. [CrossRef]

4. Davidson, E.A.; Janssens, I.A. Temperature sensitivity of soil carbon decomposition and feedbacks to climate change. Nature 2006, 440, 165-173. [CrossRef]

5. Von Lützow, M.; Kögel-Knabner, I. Temperature sensitivity of soil organic matter decomposition-What do we know? Biol. Fertil. Soils 2009, 46, 1-15. [CrossRef]

6. Takata, Y. 4.3 Andosols. In The Soils of Japan; Hatano, R., Shinjo, H., Takata, Y., Eds.; Springer: Singapore, 2021; pp. 83-90. [CrossRef]

7. Yamamoto, T.; Miyasato, S. Studies on the soil productivity of upland fields. Heavy application of phosphate mixture in Iwate volcanic ash soil. Bull. Tohoku Agric. Exp. Stn. 1971, 42, 53-92.

8. Shoji, S.; Nanzyo, M.; Dahlgren, R. Chapter 8 Productivity and Utilization of Volcanic Ash Soils. In Volcanic Ash Soils Genesis, Properties and Utilization, Developments in Soil Science, Volume 21; Shoji, S., Nanzyo, M., Dahlgren, R., Eds.; Elsevier: Amsterdam, The Netherlands, 1993; pp. 209-251. [CrossRef]

9. Munevar, F.; Wollum, A.G. Effects of the addition of phosphorus and inorganic nitrogen on carbon and nitrogen mineralization in Andepts from Colombia. Soil Sci. Soc. Am. J. 1977, 41, 540-545. [CrossRef]

10. Ogaswara, K.; Yamamoto, T. Studies on dynamics of nitrogen in upland soils. (Part 8) On application of nitrogen fertilizer with heavy application of phosphate. Tohoku Agric. Res. 1967, 8, 146-149. 
11. Sugihara, S.; Konno, T.; Ishii, K. Kinetics of mineralization of organic nitrogen in soil. Bull. Natl. Inst. Agro-Environ. Sci. 1986, $1,127-166$

12. Chan, K.Y.; Heenan, D.P. Lime-induced loss of soil organic carbon and effect on aggregate stability. Soil Sci. Soc. Am. J. 1999, 63, 1841-1844. [CrossRef]

13. Curtin, D.; Campbell, C.A.; Jalil, A. Effects of acidity on mineralization: $\mathrm{pH}$-dependence of organic matter mineralization in weakly acidic soils. Soil Biol. Biochem. 1997, 30, 57-64. [CrossRef]

14. Haynes, R.J.; Naidu, R. Influence of lime, fertilizer and manure applications on soil organic matter content and soil physical conditions: A review. Nutr. Cycl. Agroecosyst. 1998, 51, 123-137. [CrossRef]

15. Li, Y.; Wang, T.; Camps-Arbestain, M.; Suárez-Abelenda, M.; Whitby, C.P. Lime and/or phosphate application affects the stability of soil organic carbon: Evidence from changes in quantity and chemistry of the soil water-extractable organic matter. Environ. Sci. Tech. 2020, 54, 13908-13916. [CrossRef]

16. Paradelo, R.; Virto, I.; Chenu, C. Net effect of liming on soil organic carbon stocks: A review. Agric. Ecosyst. Environ. 2015, 202, 98-107. [CrossRef]

17. Takahashi, T.; Ikeda, Y.; Fujita, K.; Nanzyo, M. Effect of liming on organically complexed aluminum of nonallophanic Andosols from northeastern Japan. Geoderma 2006, 130, 26-34. [CrossRef]

18. Marumoto, T.; Okano, S.; Nishio, T. Effect of liming on the mineralization of microbial biomass nitrogen in volcanic grassland soil. Soil Microorg. 1990, 36, 5-10.

19. Wagai, R.; Kishimoto-Mo, A.; Yonemura, S.; Shirato, Y.; Hiradate, S.; Yagasaki, Y. Linking temperature sensitivity of soil organic matter decomposition to its molecular structure, accessibility, and microbial physiology. Glob. Chang. Biol. 2013, 19, 1114-1125. [CrossRef]

20. Cleveland, C.C.; Townsend, A.R.; Schmidt, S.K. Phosphorus limitation of microbial processes in moist tropical forests: Evidence from short-term laboratory incubations and field studies. Ecosystems 2002, 5, 680-691. [CrossRef]

21. Cleveland, C.C.; Townsend, A.R. Nutrient additions to a tropical rain forest drive substantial soil carbon dioxide losses to the atmosphere. Proc. Nat. Acad. Sci. USA 2006, 103, 10316-10321. [CrossRef] [PubMed]

22. Kranabetter, J.M.; Banner, A.; de Groot, A. An assessment of phosphorus limitations to soil nitrogen availability across forest ecosystems of north coastal British Columbia. Can. J. For. Res. 2005, 35, 530-540. [CrossRef]

23. Kevan, J.M.; Melany, C.F.; Peter, M.G. Calcium and phosphorus interact to reduce mid-growing season net nitrogen mineralization potential in organic horizons in a northern hardwood forest. Soil Biol. Biochem. 2011, 43, 271-279.

24. Miyazawa, M.; Takahashi, T.; Sato, T.; Kanno, H.; Nanzyo, M. Factors controlling accumulation and decomposition of organic carbon in humus horizons of Andosols. Biol. Fertil. Soils 2013, 49, 929-938. [CrossRef]

25. Saito, M. Nitrogen mineralization parameters and its availability indices of soils in Tohoku district, Japan: Their relationship. Jpn. J. Soil Sci. Plant Nutr. 1990, 61, 265-272.

26. Nedwell, D.B. Effect of low temperature on microbial growth: Lowered affinity for substrates limits growth at low temperature. FEMS Microb. Ecol. 1999, 30, 101-111. [CrossRef]

27. Bao, Z.; Matsushita, Y.; Morimoto, S.; Hoshino, Y.T.; Suzuki, C.; Nagaoka, K.; Takenaka, M.; Murakami, H.; Kuroyanagi, Y.; Urashima, Y.; et al. Decrease in fungal biodiversity along an available phosphorous gradient in arable Andosol soils in Japan. Can. J. Microbiol. 2013, 59, 368-373. [CrossRef]

28. IPCC. Climate Change 2021. The Physical Science Basis. Summary for Policymakers. 2021. Available online: https://www.ipcc. ch/report/ar6/wg1/downloads/report/IPCC_AR6_WGI_SPM_final.pdf (accessed on 1 December 2021).

29. Natali, S.M.; Holdren, J.P.; Rogers, B.M.; Treharne, R.; Duffy, P.B.; Pomerance, R.; MacDonald, E. Permafrost carbon feedbacks threaten global climate goals. Proc. Nat. Acad. Sci. USA 2021, 118, e2100163118. [CrossRef]

30. Obara, H.; Nakai, M. Available phosphate of arable lands in Japan. Changes of soil characteristics in Japanese Arable Lands (II). Jpn. J. Soil Sci. Plant Nutr. 2004, 75, 59-67. [CrossRef]

31. Rattan, L. Managing soils for negative feedback to climate change and positive impact on food and nutritional security. Soil Sci. Plant Nutr. 2020, 66, 1-9. [CrossRef]

32. Bell, S.M.; Barriocanal, C.; Terrer, C.; Rosell-Melé, A. Management opportunities for soil carbon sequestration following agricultural land abandonment. Environ. Sci. Policy 2020, 108, 104-111. [CrossRef]

33. Bai, X.; Huang, Y.; Ren, W.; Coyne, M.; Jacinthe, P.A.; Tao, B.; Hui, D.; Yang, J.; Matocha, C. Responses of soil carbon sequestration to climate-smart agriculture practices: A meta-analysis. Glob. Chang. Biol. 2019, 25, 2591-2606. [CrossRef] [PubMed] 